\title{
26. Postscript: in-pandemic academia, scholarly practices, and an ethics of care
}

Hyun Bang Shin, Yi Jin, Sin Yee Koh, Murray Mckenzie, Do Young Oh, and Yimin Zhao

As the world struggled to grasp the true scale of the COVID-I9 pandemic in early 2020, researchers and academics in higher education across the world suddenly found themselves plunging into an unchartered territory of isolation, online teaching, and a weakened boundary between home and work, if there was any such clear delineation before the pandemic. While the prevailing rhetoric was 'we are all in this together', such experiences were uneven across geographies and along the lines of gender, age, class, race, disabilities, and caring responsibilities.

With the deepening of the pandemic, the authors, located in different parts of the world (China, Malaysia, and the UK) and at diverse career stages, came together to share individual and collective experiences of the pandemic and reflect on some of the emergent literature that aims at contemplating the impact of the pandemic on society and academe. These moments of musing spanned such themes as mobility, knowledge production, ethics of care, and the future of academia.

This volume, COVID-I9 in Southeast Asia: Insights for a Postpandemic World, has brought together contributors who have all endured the pandemic-generated stress, angst, and discomfort in the context of an increasingly neo-liberalising academic environment. The contributors are also scholars whose research has been deeply rooted in Southeast Asia, a region that has much to offer to global scholarship in terms of decentring knowledge production in a world where Western scholarship has dominated.

As a way of concluding this volume, we share our own reflections on what it means to conduct academic practices during the pandemic and what the future holds for building a scholarly community that

How to cite this book chapter:

Shin, Hyun Bang; Jin, Yi; Koh, Sin Yee; Mckenzie, Murray; Oh, Do Young; and Zhao, Yimin. 2022. 'Postscript: in-pandemic academia, scholarly practices, and an ethics of care'. In: Shin, Hyun Bang; Mckenzie, Murray; and Oh, Do Young (eds) COVID-I9 in Southeast Asia: Insights for a post-pandemic world. London: LSE Press, pp. 29I-306. DOI: https://doi.org/I0.3 I389/lsepress.cov.z License: CC BY 4.0. 
challenges extant power relations and advances an ethics of care as a norm. As scholars who are either based at or were trained in global North institutions, this chapter is also part of our self-reflection on our own positionalities.

\section{Academic (im-)mobility and in-pandemic academia}

As the world began to see a rapid increase in the number of COVID-I9 cases, lockdowns eventually became the norm for many countries. Numerous media reports and scholarly works were produced to reflect on life under a 'new normal' that was said to have combined imposed physical immobility with the digitalised hypermobility of online activities (see Freudendal-Pedersen and Kesselring 202I). They have also called into question the sustainability of conventional forms of (capitalist) urbanism as a way of life.

While such experiences might have been the norm for many office workers, especially in the global North, many others were excluded from tapping into the new normal because of the inherently mobile nature of their jobs (e.g. delivery drivers, maintenance workers and operators of key infrastructure, and supermarket assistants). Pundits have also highlighted how informal workers in the global South have hardly remained locked down in order to provide services to those who were able to afford working from home. Insomuch as capitalism depends on the flow of goods and capital, it was inevitable that workers were driven to risk their well-being and lives in order to ensure that our physical infrastructure and facilities were attended to and the production of essential goods and food products continued (see Xiang 2020).

As much as the survival of our capitalist economies hinges upon the mobility of goods, capital, and labour, advancing academic careers has also depended increasingly on mobility that revolves around conference attendance, invited talks, field trips, study tours, networking, and workshops, to name only a few. For a long while, we have also been convinced that scholars throughout the world are largely members of an academic 'imagined community' (using Benedict Anderson's term) that prioritised face-to-face communications with their remote peers, facilitated by the rapid development of global transportation, especially the aviation industry. Academic mobility is further influenced by one's performance in relation to research outputs, grant applications, teaching, and service to their host institution (Lipton 2020).

The COVID-I9 pandemic significantly disturbed our routinised academic life. The global lockdown distanced most people in the world, 
including researchers and their peers, their informants, and their cooperators in other places, adding substantial difficulties to continuing ongoing research projects and developing new ones. Moreover, many funding opportunities and academic positions became at risk of disappearing due to budget cuts in the aftermath of the pandemic (Financial Times 202I). Academics were unsure at the outset of the pandemic what impact universities' decisions to switch to online distance learning would produce. This seems a cliché as the internet has already penetrated deeply into academic and daily life, but, until recently, reluctance to use webinars or virtual conferences as a mode of their operation prevailed. How will the imagined academic community operate in the (post-)pandemic era, against an increasingly hostile environment and the haunting threat of coronavirus?

The fact that the academic community can be sustained online in such a less expensive and more environmentally friendly way discloses the extant inequity within the academic community. Traditional faceto-face communications, either in lectures or in conferences, and expensive databases and academic books have created many barriers within the imagined academic community. The circulation of knowledge and the interchange of ideas have thus been limited to several centres, even if these ideas and knowledge are of and for people and places afar. In this regard, a by-product of the technology we use is a more open, inclusive, and collective academic community, and perhaps the possibility of avoiding 'embracing the trap of neoliberal scholarship' (Corbera et al. 2020, p.6).

Here, we would like to posit initially that there might still be an upside to the in-pandemic academia. The pandemic unleashed the potential of virtual communications to become one of the major modes of academic interaction at an unprecedented scale. In most cases, with just a link, scholars around the globe, especially those who had not received sufficient financial support to fund long-distance travel, could participate in online lectures and webinars they were interested in and interact with their peers whenever they were available free of charge or at minimal cost. Throughout the COVID-I9 pandemic, many scholars became or were pushed to become experts of using virtual communication tools to deliver talks, attend conferences, meet their peers, and even conduct remote interviews or $\mathrm{PhD}$ vivas. We have now become adept at picking a nice picture to veil the messy background, as well as promoting our institutions or projects. Indeed, the threshold of engaging with academic activities was dramatically lowered. Digital video conferencing platforms enabled us to virtually meet, exchange ideas, and 
continue our conversations by thinking and working collaboratively with much fewer concerns for financial pressure and overcoming the immobility and fixity generated by the pandemic.

Compared to physical travelling throughout the world, this is a vivid illustration of an academic version of what 30 years ago David Harvey (I989) called 'space-time compression'. The 'new normal' brought on by COVID-I9 has shown the potential for positive developments in the academic community. For example, the Saw Swee Hock Southeast Asia Centre at the London School of Economics and Political Science, with which the authors have been affiliated, hosted all of its research seminars and lectures online in the 2020-202I academic year. At least a third of the audience came from Southeast Asia, while many speakers also came from the region without the barrier of travel costs. Digital technologies enabled scholars in different parts of the world to connect and support each other. The authors were able to stay in touch and have a series of regular, online face-to-face meetings to reflect on the pandemic and its impact on life and scholarship, which helped them to endure the hardship of the pandemic lockdown. This volume is also the result of such efforts to give more voice to scholars in Southeast Asia.

While the affordances of such online spaces might not have been equally accessed by all, they certainly helped create spaces of solidarity by transcending physical distances and other corporeal travel barriers that would have otherwise limited participation in in-person meetings. Researchers and academics located in the southern hemisphere and the global South usually find themselves unable to participate in events hosted in the northern hemisphere and the global North owing to unaffordable travel costs and sustained travel downtimes. From workshops to writing sessions, seminars to conferences, we were suddenly spoilt for choice as webinars flourished. It seems that scholars from the global South gained access to (more) seats at the table. Their voices started to be heard, and, hopefully, will be included in collective knowledge production moving forward, as has been the case in the production of this volume, which brought together contributors working in/on Southeast Asia.

\section{Digital academe and its limits}

While the new digital mode of scholarly exchanges might be a positive development towards a more inclusive and diverse academia, the 'new normal' under the pandemic produced experiences that were unevenly 
shared depending on one's position and career stage. While experienced senior scholars were likely to continue to benefit from their established reputations, networks, and resources and practised hypermobility, early career researchers found themselves stuck in a myriad of online webinars, pixelated in gallery views on a screen that hardly allowed room for personal interactions that could help build or expand their nascent networks. Movement restrictions and tightened border controls for fear of the spread of the virus extinguished field trips, which would have been key to shaping new research projects, potentially leaving a lasting detrimental impact on those seeking tenure or promotion.

Furthermore, care and intentionality must be consciously considered and interweaved into such virtual meeting projects. In their reflections on pivoting an annual conference online, Goebel et al. (2020) have highlighted the need to consider the diverse needs of participants (e.g. from different career stages, income levels, and time zones) and the appropriateness of technologies in terms of inclusivity, privacy, and security. Most importantly, they have called for a reimagination of academic conferencing, for:

a new alternative that can address the problems related to geopolitics, continuing colonialism, the soft politics and power hierarchies in academic societies, and the alleged need for extensive and excessive physical mobility. (Goebel et al. 2020, p.8I3)

In other words, virtual platforms do offer the possibility of transcending some of the existing structures that prevent inclusive participation, but the broadening of participation alone is not enough. Conferences and workshops are key sites for building and growing networks that are crucial for future collaborations, career progression, and collective knowledge production. How might virtual (or new alternatives of) academic conferencing accord more inclusive and productive opportunities for networking that can overcome or reconfigure existing power hierarchies in academia? How might we extend, engage with, and practise care ethics (Lawson 2007) in the creation of new spaces of inclusive possibilities? These are some of the emergent questions that academe needs to address in the coming months and years.

Lastly, it is important to be aware that digital technologies also have a limit. While people in some countries have limited access or no access to video conferencing software, people in conflict zones have limited access to the internet itself. For example, access to the internet has been frequently restricted in Myanmar since the coup in February 202 I. How 
we can collaborate with and support the scholars in such challenging circumstances has become a major challenge for the rest. Furthermore, while many countries introduced technology-driven rapid responses to COVID-I9 in order to keep the rate of new infections low and reduce mortality (see Sonn, Kang, and Choi 2020 for the experience of Asian states), the integration of previously disconnected private information altogether and the implementation of various online apps to monitor movements raises concerns for the emergence of digital censorship and surveillance enabled by state-led pandemic responses (see Amnesty International 2020). Several Asian states reportedly took advantage of COVID-I9 to justify their controls over online information as well as suppression of dissent (Elemia 202I). More than roo civil society groups signed a joint statement issued by Amnesty International (2020) to prevent surveillance overreach and safeguard human rights. In fear of the pandemic, people also opted into the digital surveillance led by the state (see, for example, Chok 2020 for the case of Singapore), a phenomenon that is not new to the pandemic world but builds on path-dependency (Chung, Xu, and Zhang 2020). The implication of all these is that the emergent digital opportunities are to be received with caution for heightened possibilities of digital censorship and surveillance that might also affect critical scholarship.

\section{Hyper-productivity versus slow scholarship}

The neo-liberal university had pushed us relentlessly, and the pandemic added salt to the wound. During the pandemic, our workloads increased tremendously, our personal spaces of rest and recuperation invaded and taken over by ever-expanding work that has crept into our lives and our homes. Burnout is rampant, affecting academics worldwide across all career stages (De Gruyter 2020; Gewin 202I; McMurtie 2020), and such hardship might have been felt more strongly among those with additional care responsibilities and health vulnerabilities. Where does work end? Does it end? Where and how do we draw boundaries? Can we afford to draw boundaries in the here and now, without unknowingly compromising our futures? Indeed, as Behrisch (202 I, p.673) has reminded us, there is 'an opportunity cost to caring [for the self and others], which is not rewarded within neoliberal culture'. As we pondered these questions, in our isolated bubbles that were somewhat out of sync with others who were in differing stages of lockdown, our place within in- and post-pandemic academia came to appear even more uncertain. Where and how do we go next? 
Shock and uncertainty were among people's first experiences during the pandemic. They were accordingly shaping our problematics and practices of knowledge production. To do our best to capture the pandemic conditions and their effects, as well as to respond to situations of uncertainty, it would have been very tempting to write and disseminate 'knowledge' as quickly as possible. The dilemma between instant reaction and in-depth reflection is hence brought to the fore and is worth further interrogation. The World Health Organization, for instance, issued its interim guidance on strengthening urban preparedness for COVID-I9 in early 2020, when the pandemic was just beginning to unfold (WHO 2020). While it aimed to guide local authorities across the world to take action, the document turned out to be an encompassing void - saying everything and hence nothing. Worse still, we also saw presumptions raised with no solid evidence. For example, it referred to 'the ease of introduction and spread of the virus' in densely populated areas (WHO 2020, p.4), amplifying a long-lasting stigma towards certain urban spaces and residents and testifying, to some extent, what McFarlane (202I, p.6) has termed '[a]n imaginary of density-as-pathology' (original emphasis).

The rush to fast production without adequate evidence is not limited to the policy sphere alone. Among the pages of academic journals, similarly, we also saw a quick rise of commentaries and short interventions tackling the conditions of the pandemic. While some of them were relevant and timely in contributing to the collective scholarly response to this pandemic, some others were by and large putting old wine into new bottles, expecting to get more attention or citation with the pandemic as a new buzzword (hashtag) even though little empirical evidence was collected or presented. All of these added fuel to the fire of academe's prevailing culture of hyper-productivity.

The expectation of hyper-productivity might not have been explicitly spelt out but nevertheless was implicitly felt and internalised by many in the neo-liberal university. The metrification of academic work, which continued uninterrupted during the pandemic, 'placed new demands on academics to perform productively and reinvent the self' (Lipton 2020, p.3). Even as some of us succeed in becoming more efficient and more productive, the gauges of 'excellence' are continually being recalibrated upwards. We have no choice but to try to keep up and catch up. The metrified outputs of academics' intellectual work - most notably their publications and grants - cannot be miraculously produced in thin air or through a cookie cutter assembly line. Uninterrupted periods of gestation for deep work and critical reflection are the necessary ingredients 
for work that can deliver conceptual resonance across empirical contexts. But time and intellectual head space for cognitive processes were increasingly scarce luxuries for many of us during the pandemic. As De Gruyter's (2020, p.I8) report on the impact of the pandemic on academics and academic publishing concluded,

the pandemic has, and continues to be, a time of great stress, insecurity and pressure. These are pressures that will cause career-defining damage that impacts the individual but will also have significant repercussions for scholarship, equality, diversity and research innovation.

The repercussions are either damagingly long working hours to maintain hyper-productivity, erasing time for recuperation and family life, or poorly baked outputs that are equally damaging.

As members of the academic community, we want to call for more ripe reflections and the need to keep a greater distance from such conduct, not least because it is an emerging form of the inflated commodification of knowledge production, inflected by various impact factors and rankings that have long haunted academia. Here, we summon debates on slow scholarship that emerged in the 20I0s, well before the pandemic (Martel 20I4; Mountz et al. 20I5), combined with attention to collective resistance, careful work, and intentional collaboration (e.g. Jones and Whittle 202I; Shahjahan 2014; Wahab, Mehrotra and Myers 202I).

We have certainly been sympathetic to the tendency to respond quickly during the pandemic when so many lives were in danger; however, we see it equally necessary to study this pandemic state of emergency with deep reflection, always focusing on actually existing situations and attending to dialectical relations between instant reaction and in-depth reflection, which might eventually lead us to what David Harvey (2020) would call the 'collective response'. There is no given end to any form of knowledge production in/of the pandemic since the situation is always unsettled. What we should do is respond to ever-changing pandemic conditions collectively, use any convenient way to observe, dialogue, and write, and continue developing those lines of inquiry with colleagues near and far.

There are already plenty of good examples of this kind of knowledge production. Arundhati Roy (2020), for instance, has depicted the 'portal' through which this pandemic was put into play in India. This portal not only revealed the realpolitik at the time of her writing that shaped the Indian government's infamous response to the pandemic 
a year later, but also explained how and how far this tragedy, though immediate, real, and epic, would not be new at all. 'The tragedy is the wreckage of a train that has been careening down the track for years', says Roy. These sentences were written in April 2020, and they still worked, even more so, in the spring of $202 \mathrm{I}$, when such tragedies became much worse in the same country on the same 'track'. Xiang Biao (2020), on the other hand, has shifted his focus to the social production and reproduction of (hyper-)mobility, endeavouring to explore what happens when global and national economies become hostages of mobility on the one hand, while such mobility is being disturbed by the pandemic on the other. Outside academia, intellectuals and writers of other kinds also worked in their own ways to record the here and now of the pandemic, works that are also worth our attention when documenting the knowledge production in/of the pandemic. The diary of Fang Fang (2020), a novelist living in Wuhan, could be a good case of this kind; both its contents and related controversy in China are artefacts of the pandemic that invite further analysis.

\section{Decolonising scholarship}

The imposed restrictions on mobility raise questions about extant practices of knowledge production and academic collaboration, calling for greater attention to new opportunities for decentring academic scholarship in a way that allows room for the growth and independence of local scholarship without subordination to the hegemony of the global North. Conventional international collaborations have been heavily influenced by funding regimes that position scholars in the global North as principal or co-investigators of large grants, while rendering scholars in field sites of the global South local collaborators who carry out data collection based on the prescribed research parameters by grant-holders. The pandemic-generated difficulties in international travel acted as a double-edged sword. On the one hand, they might have aggravated the existing inequity in scholarship by reinforcing the positions of local scholars as data collectors. On the other hand, it might have opened up a new opportunity for local scholars to be able to participate in research projects on a more level playing field based on their superior local knowledge that cannot be stolen by occasionally 'parachuting in' grant-holders. It is the latter that we hope to see blossoming, responding to the emergent calls for decentring knowledge production and decolonising academia. 
While the pandemic opened a door to new opportunities that connect scholars across geographies, there is still a challenge for academe to overcome the existing hierarchies that favour the scholarship of the global North. The pandemic environment raised the possibility of immediate hardship to be given priority over a longer-term imperative of building a horizontal network of scholarship to advance the decolonisation agenda in higher education. These issues demonstrate the enduring relevance of Massey's (2004) point, projected through the imperatives of postcolonial thought (e.g. Jazeel and McFarlane 20I0; Raghuram, Madge, and Noxolo 2009), that the outward-looking politics of one's connectivity to geographically and professionally distant others is all too easily made secondary to more proximate and immediate concerns.

Amid the myriad personal and professional challenges that the pandemic entailed - challenges that reinforce the fact that being able to write and publish one's thoughts on responsibility already betrays some amount of privilege - the legacies of colonialism have been made readily apparent in the fact that many of the most well-resourced scholars writing on Southeast Asia and other parts of the global South are affiliated with Euro-American research institutions. It is also true, although to a lesser extent than one might expect, of published scholarship. Of the first 856 English-language articles that we collected on COVID-I9 in the fields of development, human geography, planning, and urban studies, we found that 7 I.I\% of their first authors are based at institutions in Europe, North America, or Australia and New Zealand. This is an improvement on the percentages of $95.0 \%$ and higher that were found in major geography journals by Jazeel (2019, pp.202-203) half a decade earlier.

Such challenges have served as an impetus for geographers' recently mounting efforts to supplement postcolonial and subaltern methodologies by engaging more concertedly with decoloniality and its challenge to the legacies of colonial power preserved in the dominance of the global university and its associated epistemes (see Radcliffe 20I7). The epistemological basis for this agenda has been furnished largely by the modernity/(de)coloniality programme, a highlight of which is Mignolo's (2002) argument that coloniality's entanglement with modernity is manifest in the contemporary geopolitics of knowledge that grounds Western epistemology - even when entrained in critical, Marxian, and postcolonial theoretical interventions - in a 'spatial articulation of power' (p.60) that is ineluctably colonial in its disposition. 
In this regard, and in light of the pandemic-generated constraints on mobility, we call for the rise of critical scholarship whose line of enquiries by locally embedded scholars starts from the locality where the concrete web of life unfolds and is in need of transformation. Such enquiries are to produce an informed understanding of the locality that is situated in the interdependence of all places, to be followed by the reinterpretation and intervention by the enquirers. While we see such practices as part of decentring and decolonising the production of knowledge by adopting 'a pluralistic world view' as a means to challenge the Western hegemony of scholarship, we are also mindful of how such approaches 'may risk falling into the epistemological pitfall of liberal pluralistic thinking, and that a preoccupation with multiplying and pluralising references can potentially neutralise or bypass historical violence and structural hierarchies' (Hae and Song 20I9, p.I I).

Therefore, it is important to exercise inter-referencing within Asia (and, for this volume, Southeast Asia in particular) in a way that does not entail the erection of another methodological regionalism. This entails the recognition of 'linguistic fluidity' (Chen 20I0; see also Zhao 2020), which produces a diverse range of translated versions of a concept born out of the experience of the Western modernity. Such fluidity is an indication of how political cultures in (Southeast) Asia can be diverse and differentiated from the West. We ask for more active contributions of locally based scholars who work in and on Southeast Asia, embedded in a horizontal network of scholars across the world, so that pandemic-generated (im-)mobility becomes not a testimony of isolated and individualised regional scholars but an opportunity to rebuild a new network of researchers equipped with decolonising imperatives that contribute to the demolition of existing hierarchies of scholarship. We hope that the co-authorship of this chapter is a small step towards this rebuilding.

\section{Coda: ethics of care}

Throughout the pandemic's unpredictable course, surviving and withstanding its threats very much depended on the deepened feelings of care and compassion that COVID-I9 motivated. It is this ethics of care to which we turn as we conclude this chapter, for, while a 'resurgence of reciprocity' (Springer 2020 , p.II2) in the form of mutual aid during COVID-I9 provided much that is of interest to the critical social sciences - as is readily apparent in the pages of this book - it also imparted a renewed salience to the question of the social and political 
responsibilities that are attendant on the production of geographical knowledge (Massey 2004).

For many scholars, the pandemic renewed the challenge of what Massey (2004, pp.8-9) has called 'a hegemonic geography of care and responsibility': a geography that privileges the near over the far and that manifests in distinctly territorial forms. As Massey has acknowledged, there are many reasons for this geography's persistence. Those most apparent for scholars during COVID-I9 included the disproportionate burdens of childcare and other domestic responsibilities placed on many academic mothers (Minello, Martucci, and Manzo 2020) and the anxieties of job insecurity and poor working conditions that preoccupied many early career academics (Kinikoğlu and Can 2020). Broadly, as Corbera et al. (2020) have argued, the pandemic highlighted the dearth of care, pluralism, solidarity, and well-being in normal academic practices, for which the pursuit of various standards of professional 'excellence' is often the overriding and unrelenting motive.

The aim of our knowledge production should not be the total number of downloads or citations but instead an ethics of care (Corbera et al. 2020) - the conduct of being collaborative in developing this collective response, we would say, is in itself a form of care and a critical part of the new ethics (see also Shin 202I, pp.67-68). The authors of this chapter have certainly benefited from the regular online meetings we held in 2020 , which helped us to form a collective response to a collective dilemma of pandemic constraints without having to feel the urge of rushing into hypermobility and hyper-productivity. Our collective endeavour has also made us realise the importance of maintaining a horizontal network of scholars to overcome an increasingly hostile work environment in higher education and of establishing practices of knowledge production as an exercise that is collaborative, with the pandemic producing new inter-connectivities across great distances, and perhaps even that is therapeutic (in the sense of helping cope with distressing times). Ultimately, we hope an ethics of care becomes the foundation of critical scholarship that is not only confined to the space of the pandemic but a general practice in academia.

\section{References}

Amnesty International. (2020). Joint Civil Society Statement: States Use of Digital Surveillance Technologies to Fight Pandemic Must Respect Human Rights. https://perma.cc/PZH8-RSQD [Last accessed I9 June 202 I]. 
Behrisch, Tanya J. (202I). 'Cooking a pot of beef stew: Navigating through difficult times through slow philosophy'. Qualitative Inquiry, vol. 27, no. 6, pp. 667-676. https://doi.org/IO.I I 77/I07780042094I057

Chok, Lazarus. (2020). 'The policy black box in Singapore's digital contact tracing strategy'. LSE Southeast Asia Blog, 22 September. https://perma.cc /NC28-325G [Last accessed I9 June 202I].

Chung, Calvin King Lam; Xu, Jiang; and Zhang, Mengmeng. (2020). Geographies of Covid-ı9: how space and virus shape each other. Asian Geographer, vol. 37, no. 2, pp. 99-I I6. https://doi.org/IO.I080/I0225706 .2020 .1767423

Corbera, Esteve; Anguelovski, Isabelle; Honey-Rosés, Jordi; and Ruiz-Mallén, Isabel. (2020). 'Academia in the time of COVID-I9: Towards an ethics of care'. Planning Theory and Practice, vol. 2I, no. 2, pp. I9 I-99. https://doi .org/IO.IO80/I 4649357.2020.I75789I

De Gruyter. (2020). Locked Down, Burned Out. Publishing in a Pandemic: The Impact of Covid on Academic Authors. Germany: De Gruyter. https:// perma.cc/YBP9-NW 4 W [Last accessed I 2 June 202I].

Elemia, Camille. (202I). 'At least ıo Asia Pacific gov'ts use COVID-I9 for censorship, disinformation'. Rappler, 20 April. https://perma.cc/7WKC-8DY2 [Last accessed I9 June 202I].

Fang, Fang. (2020). Wuhan Diary: Dispatches from a Quarantined City. UK: HarperCollins.

Financial Times. (2020). 'UK funding cuts are a slap in the face for science', 7 April. https://perma.cc/V5ES-QHE2 [Last accessed 25 June 202I].

Freudendal-Pedersen, Malene; and Kesselring, Sven. (202I). 'What is the urban without physical mobilities? COVID-I9-induced immobility in the mobile risk society'. Mobilities, vol. I6, no. I, pp. 8I-95. https://doi.org/I0.I080 /I7450IOI.2020.I846436

Gewin, Virginia. (202I). 'Pandemic burnout is rampant in academia'. Nature, vol. 59I, no. 7850 , pp. 489-49I. https://doi.org/IO.IO38/d4I 586-O2 I $-00663-2$

Goebel, Janna; Manion, Caroline; Millei, Zsuzsa; Read, Robyn; and Silova, Iveta. (2020). 'Academic conferencing in the age of COVID-I9 and climate crisis: The case of the Comparative and International Education Society (CIES)'. International Review of Education, vol. 66, no. 5-6, pp. 797-8 I 6. https://doi.org/IO. I007/s I I I 59-020-09873-8

Hae, Laam; and Song, Jesook. (2019). 'Introduction: Core location, Asia as method, and a relational understanding of places', in Jessok Song and Laam 
Hae (eds) On the Margins of Urban South Korea: Core Location as Method and Praxis. Canada: University of Toronto Press, pp. 3-20.

Harvey, David. (2020). 'We need a collective response to the collective dilemma of coronavirus'. Jacobin, 24 April. https://perma.cc/TP 58 -FLVS [Last accessed 25 June 202I].

Harvey, David. (I989). The Condition of Postmodernity: An Enquiry into the Origin of Cultural Change. UK: Blackwell.

Jazeel, Tariq. (2019). Postcolonialism. UK: Routledge.

Jazeel, Tariq; and McFarlane, Colin. (2010). 'The limits of responsibility: a postcolonial politics of academic knowledge production'. Transactions of the Institute of British Geographers, vol. 35, no. I, pp. I09-I 24. https://doi .org/IO.I I I I/j.I 475-566I.2009.00367.X

Jones, Craig Henry; and Whittle, Rebecca. (202I). 'Researcher self-care and caring in the research community'. Area, vol. 53, no. 2, pp. $38 \mathrm{I}-388$. https:// doi.org/IO.I I I I/area.I 2703

Kinikoğlu, Canan Neşe; and Can, Aysegul. (2020). 'Negotiating the different degrees of precarity in the UK academia during the Covid-I9 pandemic'. European Societies, vol. 23, no. I, pp. S8I7-30. https://doi.org/I0.1080/I 4 6I 6696.2020.1 839670

Lawson, Victoria. (2007). 'Geographies of care and responsibility'. Annals of the Association of American Geographers, vol. 97, no. I, pp. I-I I. https:// doi.org/IO.I I I I/j.I 467-8306.2007.00520.X

Lipton, Briony. (2020). Academic Women in Neoliberal Times. Switzerland: Springer International Publishing.

Martell, Luke. (20I4). 'The slow university: Inequality, power and alternatives'. Forum Qualitative Sozialforschung/Forum: Qualitative Social Research, vol. I 5, no. 3 , pp. Io. https://doi.org/IO.I 7 I 69/fqs-I 5.3.2223

Massey, Doreen. (2004). 'Geographies of responsibility'. Geografiska Annaler: Series B, Human Geography, vol. 86, no. I, pp. 5-I8. https://doi.org /IO.I I I I/j.0435-3684.2004.00I 50.X

McFarlane, Colin. (202I). 'Repopulating density: COVID-I9 and the politics of urban value’. Urban Studies. https://doi.org/IO. I I 77/004209802 I IO I 48 IO

McMurtie, Beth. (2020). 'The pandemic is dragging on. Professors are burning out'. The Chronicle, 5 November. https://perma.cc/M9F2-XZHM [Last accessed I 2 June 202I].

Mignolo, Walter. (2002). 'The geopolitics of knowledge and the colonial difference'. The South Atlantic Quarterly, vol. Ior, no. I, pp. 57-96. https://doi .org/IO.I2I 5/OO382876-IOI-I-57 
Minello, Alessandra; Martucci, Sara; and Manzo, Lidia K.C. (2020). 'The pandemic and the academic mothers: Present hardships and future perspectives'. European Societies, vol. 23, no. I, pp. S82-94. https://doi.org/IO. Io 80/I 46 I 6696.2020. I 809690

Mountz, Alison; Bonds, Anne; Mansfield, Becky; Loyd, Jenna; Hyndman, Jennifer; Walton-Roberts, Margeret; Basu, Ranu; Whitson, Risa; et al. (2015). 'For slow scholarship: A feminist politics of resistance through collective action in the neoliberal university'. ACME: An International E-Journal for Critical Geographies, vol. I4, no. 4, pp. I235-I 259.

Radcliffe, Sarah A. (20I7). 'Decolonising geographical knowledges'. Transactions of the Institute of British Geographers, vol. 42, no. 3, pp. 329-333. https://doi.org/IO. I I I I/tran. I 2 I95

Raghuram, Parvati; Madge, Clare; and Noxolo, Pat. (2009). 'Rethinking responsibility and care for a postcolonial world'. Geoforum, vol. 40, no. I, pp. 5-I3. https://doi.org/IO.IOI6/j.geoforum.2008.07.007

Roy, Arundhati. (2020). 'The pandemic is a portal'. Financial Times, 4 April. https://perma.cc/76Z8-UXZD [Last accessed 25 June 202I].

Shahjahan, Riyad A. (20I4). 'From "no" to "yes": Postcolonial perspectives on resistance to neoliberal higher education'. Discourse: Studies in the Cultural Politics of Education, vol. 35, no. 2, pp. 219-232. https://doi.org/IO.1080 lOI 596306.2012 .745732

Shin, Hyun Bang. (202I). 'Theorising from where? Reflections on de-centring global (Southern) urbanism', in Colin McFarlane and Michele Lancione (eds) Global Urbanism: Knowledge, Power and the City. UK: Routledge, pp. 62-70.

Sonn, Jung Won; Kang, Myounggu; and Choi, Yeol. (2020). Smart city technologies for pandemic control without lockdown. International Journal of Urban Sciences, vol. 24, no. 2, pp. I49-I 5 I. https://doi.org/IO.IO80/I 226 5934.2020.1764207

Springer, Simon. (2020). 'Caring geographies: The COVID-I9 interregnum and a return to mutual aid'. Dialogues in Human Geography, vol. 10, no. 2, pp. I I 2-I I 5. https://doi.org/IO. I I 77/204382062093 I 277

Wahab, Stéphanie; Mehrotra, Gita R.; and Myers, Kelly E. (202 I). 'Slow scholarship for social work: A praxis of resistance and creativity'. Qualitative Social Work. https://doi.org/IO.I I 77/I47332502 I990865

World Health Organization (WHO). (2020). Strengthening Preparedness for COVID-I9 in Cities and Urban Settings: Interim Guidance for Local Authorities. Switzerland: WHO. https://perma.cc/2TD9-AN88 [Last accessed 25 June 202I]. 
Xiang, Biao. (2020). 'The gyroscope-like economy: hypermobility, structural imbalance and pandemic governance in China'. Inter-Asia Cultural Studies, vol. 2I, no. 4, pp. 52I-532. https://doi.org/IO.IO80/I4649373.2020.I 8 32305

Zhao, Yimin. (2020). 'Jiehebu or suburb? Towards a translational turn in urban studies'. Cambridge Journal of Regions, Economy and Society, vol. I3, no. 3, pp. 527-542. https://doi.org/IO.I093/cjres/rsaaO32 